\title{
Sequence analysis of an Archaeal virus isolated from a hypersaline lake in Inner Mongolia, China
}

\author{
Eulyn Pagaling ${ }^{\dagger 1}$, Richard D Haigh ${ }^{\dagger 1}$, William D Grant ${ }^{1}$, Don A Cowan ${ }^{2}$, \\ Brian E Jones ${ }^{3}$, Yanhe $\mathrm{Ma}^{4}$, Antonio Ventosa ${ }^{5}$ and Shaun Heaphy*1
}

\begin{abstract}
Address: ${ }^{1}$ Department of Infection Immunity and Inflammation, University of Leicester, University Road, Leicester, LE1 9HN, UK, ${ }^{2}$ Department of Biotechnology, University of the Western Cape, Bellville 7535, Cape Town, South Africa, ${ }^{3}$ Genencor International B, V., Archimedesweg 30 , 2333 CN Leiden, The Netherlands, ${ }^{4}$ State Key Laboratory of Microbial Resource, Institute of Microbiology, Chinese Academy of Sciences, Beijing, 100080, China and ${ }^{5}$ Department of Microbiology and Parasitology, Faculty of Pharmacy, University of Sevilla, Sevilla, 41012, Spain

Email: Eulyn Pagaling - eulyn_pagaling@hotmail.com; Richard D Haigh - rxh@le.ac.uk; William D Grant - wdg1@le.ac.uk; Don A Cowan - dcowan@uwc.ac.za; Brian E Jones - bejones@xs4all.nl; Yanhe Ma - mayanhe@im.ac.cn; Antonio Ventosa - ventosa@us.es; Shaun Heaphy* - sh1@le.ac.uk

* Corresponding author †Equal contributors
\end{abstract}

Published: 9 November 2007

BMC Genomics 2007, 8:410 doi:10.1186/147I-2164-8-410
Received: 12 July 2007

Accepted: 9 November 2007

This article is available from: http://www.biomedcentral.com/I47I-2/64/8/4I0

(c) 2007 Pagaling et al; licensee BioMed Central Ltd.

This is an Open Access article distributed under the terms of the Creative Commons Attribution License (http://creativecommons.org/licenses/by/2.0), which permits unrestricted use, distribution, and reproduction in any medium, provided the original work is properly cited.

\begin{abstract}
Background: We are profoundly ignorant about the diversity of viruses that infect the domain Archaea. Less than 100 have been identified and described and very few of these have had their genomic sequences determined. Here we report the genomic sequence of a previously undescribed archaeal virus.

Results: Haloarchaeal strains with I6S rRNA gene sequences $98 \%$ identical to Halorubrum saccharovorum were isolated from a hypersaline lake in Inner Mongolia. Two lytic viruses infecting these were isolated from the lake water. The BJI virus is described in this paper. It has an icosahedral head and tail morphology and most likely a linear double stranded DNA genome exhibiting terminal redundancy. Its genome sequence has 42,27 I base pairs with a GC content of $\sim 65 \mathrm{~mol} \%$. The genome of $\mathrm{BJI}$ is predicted to encode $70 \mathrm{ORFs}$, including one for a tRNA. Fifty of the seventy ORFs had no identity to data base entries; twenty showed sequence identity matches to archaeal viruses and to haloarchaea. ORFs possibly coding for an origin of replication complex, integrase, helicase and structural capsid proteins were identified. Evidence for viral integration was obtained.

Conclusion: The virus described here has a very low sequence identity to any previously described virus. Fifty of the seventy ORFs could not be annotated in any way based on amino acid identities with sequences already present in the databases. Determining functions for ORFs such as these is probably easier using a simple virus as a model system.
\end{abstract}

\section{Background}

The three domain description of cellular life on earth, Eukarya, Bacteria and Archaea is a firmly established biological tenet [1]. Each domain has an associated, probably vastly diverse, virus population [2-6]. Thousands of viruses infecting representatives of the domain Eukarya have been described and many of their DNA/RNA genomic sequences determined [7]. Something like 5- 
6000 viruses (bacteriophages) infecting representatives of the domain Bacteria have been described, at least morphologically, although rather fewer DNA/RNA genomic sequences have been determined [8]. In contrast we are largely ignorant about viruses infecting representatives of the domain Archaea. Just 40 or so have been described and the genomic sequences of only a few have been determined, sixteen being listed in Genbank. All archaeal viruses so far discovered have dsDNA genomes, both linear and circular $[8,9]$. Archaeal viruses having an RNA genome have not yet been identified and perhaps do not exist [9].

The domain Archaea is divided into four established kingdoms, the Crenarchaeota, the Euryarchaeota, the uncultivated Korarchaeota and the very recently identified Nanoarchaeota $[10,11]$. Virus particles associated with the first two phyla have been identified, recently reviewed in [9]. About 24 viruses of crenarchaeotes have been identified, often with unusual shapes, e.g. droplets and bottle shapes never observed elsewhere; these viruses have no obvious relationship to phage infecting members of the domain Bacteria [8,9]. Similarly about 20 viruses infecting members of the Euryarchaeota have been identified of which 15 infect haloarchaea, recently reviewed in [12]. These are mostly head/tail viruses of the order Caudovirales, including myoviruses and siphoviruses that may be distantly related to those infecting the domain Bacteria $[8,9]$; although other morphotypes have also been observed [12]. Only six viruses of the haloarchaea have been sequenced. All were isolated by the Dyall-Smith laboratory in Melbourne, from hypersaline sources in Australia, except for $\phi \mathrm{Ch} 1 . \phi \mathrm{Ch} 1$, a temperate myovirus with a $58.5 \mathrm{~kb}$ linear genome, the host of which is the haloalkaliphile Natrialba magadii [13] was isolated from a laboratory strain and presumably originates, like the host, from Africa. Lytic viruses HF1 and the closely related HF2, having linear genomes of $75.9 \mathrm{~kb}$ and $77.7 \mathrm{~kb}$, infect the haloarchaea Haloferax lucentense and Halorubrum coriense respectively $[14,15]$. His1 and the distantly related His2 spindle shaped viruses with linear genomes of 14.5 and $16 \mathrm{~kb}$ respectively, both have lytic and carrier status in Haloarcula hispanica [16]. Finally a lytic icosahedral virus SH1, having a linear genome of $31 \mathrm{~kb}$ infects Har. hispanica $[17,18]$.

We have been studying both archaeal and bacterial prokaryotic diversity in Chinese salt lakes in Inner Mongolia; as part of this study we looked for virus particles associated with haloarchaea. In this report we describe the complete genomic sequence of a $\sim 43 \mathrm{~kb}$ virus BJ1.

\section{Results}

\section{Description of site and lake water parameters}

Lake Bagaejinnor is a hypersaline lake in Inner Mongolia, China [coordinates N45 08527 E116 36 167]. The lake was sampled in September 2003. It had substantially evaporated over the summer, exposing expanses of [pink salt - encrusted] mud flats and had been reduced to small pools and lagoons of salt - saturated colourless water, $\mathrm{pH}$ 8.5. The pink colouration of the salt crystals indicated the presence of haloarchaea. The chemical composition of lake water was determined using laser inductively coupled plasma optical emission spectrometry by the Department of Geology, University of Leicester. Carbonate/bicarbonate concentrations were determined by titration with $\mathrm{H}_{2} \mathrm{SO}_{4}$ using a Digital Titrator Model 16900 according to manufacturer's instructions (Hach Systems for Analysis). Chemical concentrations were $\mathrm{Na}, 5.32 \mathrm{M} ; \mathrm{Cl}, 4.61 \mathrm{M} ; \mathrm{S}$ $1.07 \mathrm{M} ; \mathrm{Mg}, 0.35 \mathrm{M}$; K, $33.25 \mathrm{mM} ; \mathrm{Br}, 8.05 \mathrm{mM}^{\mathrm{HCO}} \mathrm{HCO}_{3}$ $7.4 \mathrm{mM}$; B, $4.25 \mathrm{mM}$; $\mathrm{CO}_{3}, 3.3 \mathrm{mM}$; Ca, $0.77 \mathrm{mM}$; Li, 0.33 $\mathrm{mM}$.

Obviously this is a seasonal chemical analysis of the lake water, the composition of which continually varies, more dilute in spring following the winter thaw and then gradually becoming concentrated by the hot summer winds. We used trial and error techniques to find an appropriate medium where we could pour both top and bottom agars. Medium composition was influenced by very high salt concentrations interfering with agar solidification and causing "salting out" of some of the components. The eventual salt composition of this medium was identical to that determined for the lake above with the following exceptions; $\mathrm{Na}$ was at $2.85 \mathrm{M}, \mathrm{Cl}$ was at $2.6 \mathrm{M}, \mathrm{S}$ was at $0.642 \mathrm{M}, \mathrm{Ca}$ and Li were omitted completely.

\section{Identification of a haloarchaeal host}

Virus BJ1 was isolated from the water column of Lake Bagaejinnor and propagated using strain BJ1 B11. The host was characterised by $16 \mathrm{~S}$ rRNA gene sequence using both forward and reverse primers, giving 1305 bp of sequence [EMBL: AM412370]. Strain BJ1 B11is most closely related, at $98 \%$ identity, to Halorubrum saccharovorum with 1289 identical nucleotides. It is also closely related to Hrr. lacusprofundi (1283 identical nucleotides) and the recently described Hrr. aidingense (1286 identical nucleotides). All three species were originally isolated from hypersaline environments, a salt pan in San Francisco, Deep lake Antarctica and Xin-Jiang in China respectively $[19,20]$. Fig 1 is a phylogenetic tree showing the relationship of the $\mathrm{BJ} 1 \mathrm{~B} 11$ isolate to other closely related sequences present in the BLAST database.

\section{Plaque morphology}

Plaques for BJ1 required one to two weeks to appear on plates because the host is slow growing. Plaque size for 


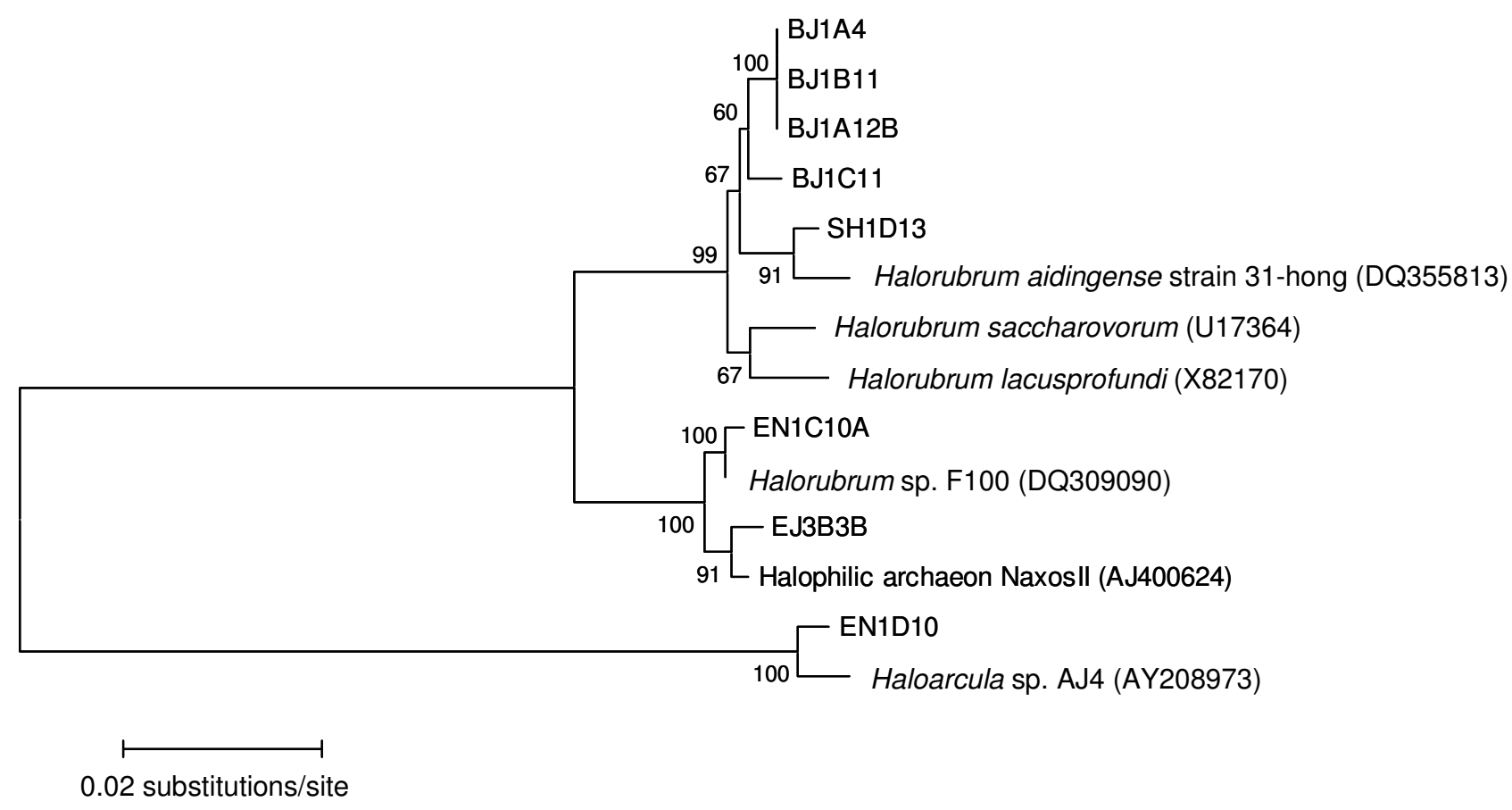

\section{Figure I}

Unrooted phylogenetic tree showing the relationship of the environmental archaeal strain host BJIBII for the virus BJI, to other closely related environmental strains isolated by us and Halorubrum species. The scale bar represents the number of inferred nucleotide substitutions per site. Values at nodes indicate $>50 \%$ percentage occurrence in 500 bootstrapped trees.

BJ1 was variable between experiments ranging from 1-5 $\mathrm{mm}$ in diameter, probably due to slight changes in growth conditions; they were also irregularly shaped and turbid. No attempt was made to optimise plaque formation by modifying temperature, salt concentrations or host strain.

\section{Electron microscopy}

Virus BJ1 has an icosahedral head, collar and tail, (Fig. 2). The icosahedral head usually has an electron dense shadowing in the centre. The sizes of these features are shown in the schematic diagram Fig 2 . The length of a single vertex is $28 \mathrm{~nm}$. The average length of an entire virus particle is about $127 \mathrm{~nm}$. The virus appears to be non-contractile and can be tentatively assigned to the Siphoviridae family, (see the Discussion).

\section{Characterisation of virus genome}

The genomic nucleic acid was tested for susceptibility to various nucleases (Fig 3) Control experiments showed that no virus - associated nucleases were responsible for the degradation observed in these experiments. Fig. 3, lanes 1 and 4 show undigested genome controls, lane 2 shows that the genome was sensitive to DNase I digestion and lane 3 shows that the genome was insensitive to
RNAse A. Susceptibility to a wide range of double strand - specific endonucleases i.e BamHI, HaeIII, SstI and XhoI, confirmed that the DNA was double stranded e.g. (Fig 3, panel c). Exonuclease III, specific for linear or nicked circular dsDNA, failed to cut circular double stranded DNA plasmid DNA controls (not shown) but substantially degraded virus genomic DNA (Fig 3 panel a, lane 5). Thus BJ1 probably has a linear dsDNA genome, although the possibility that it is a nicked circular genome cannot be completely ruled out.

Genomic nucleic acid ran on 1.2\% TAE agarose gels as a discrete single band larger than a $23 \mathrm{~kb}$ DNA marker band. (data not shown). PFGE also suggested a genomic size greater than $23 \mathrm{~kb}$ but less than $48 \mathrm{~kb}$ (Fig 3, panel b). Bam $\mathrm{H} 1$ digestion of the genomic DNA gave 21 discrete bands ranging in size from $6.5 \mathrm{~kb}$ to $~ 500 \mathrm{bp}$ (Fig 3, panel c). From the size of these fragments we estimated a genome size of $42.7 \mathrm{~kb}$, remarkably close to the size eventually determined by sequencing ( $42.271 \mathrm{~kb}$, see below). In silico digestion of the determined sequence with $\mathrm{Bam} \mathrm{HI}$ showed that it would generate 20 different fragments i.e. 4949, 4661, 3762, 3235, 3185, 2952, 2434, 2406, 2004, 1949, 1679, 1617, 1505, 1314, 1275, 1094, 816, 781, 


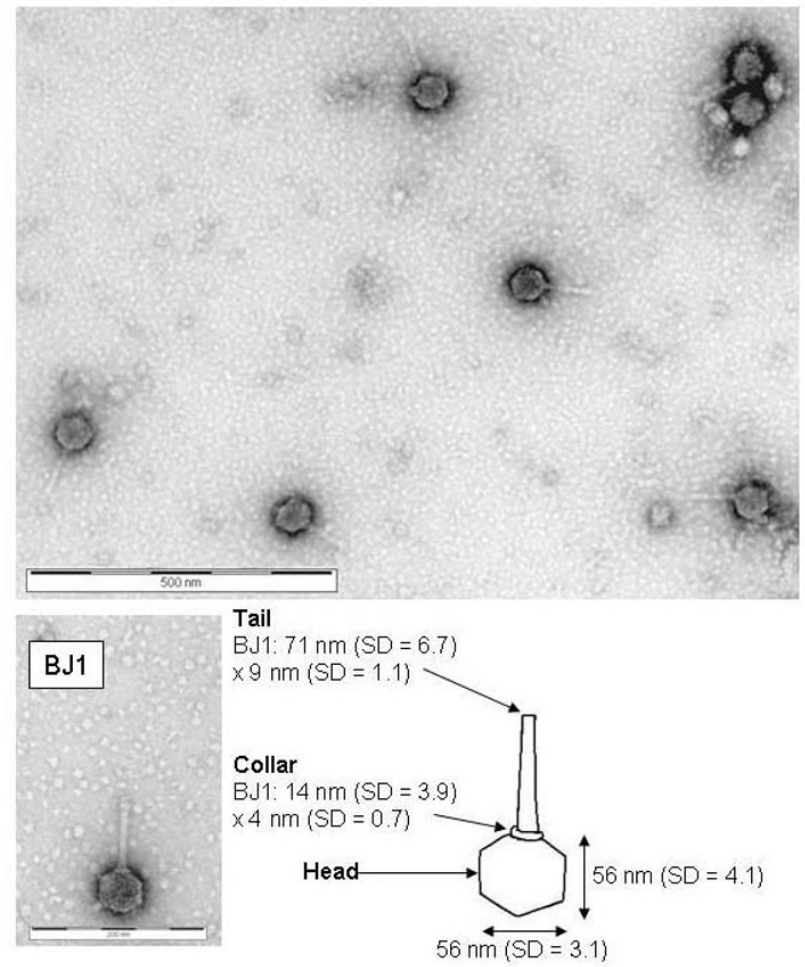

Figure 2

Electron micrograph images of $\mathrm{BJI}$; the scale bar is $500 \mathrm{~nm}$, top panel and $200 \mathrm{~nm}$ bottom panel. A schematic diagram of BJI annotated with discernible features and the size of these features is also shown. The standard deviation (SD) of measurements from twenty six different particles was determined.

563, and 90 bps, with sizes in close agreement to those we observed. Thus the genomic DNA is not subject to methylation at BamHI sites.

\section{Genome sequence of $B \boldsymbol{J}$}

See Figure 4 and Table 1 . The double stranded genomic DNA isolated from virus particles is shown as a circular sequence 42, 271 bp long with a $\mathrm{G}+\mathrm{C}$ content of 64.8 mol\% [EMBL: AM419438]. Exonuclease III susceptibility showed that the DNA is linear but sequence assembly indicated it to be circular. This indicates that the genome is terminally redundant (and may be circularly permuted). It is unclear if the BJ1 genome ever forms a circular molecule but if it does then cos sites are unlikely to be involved as digests with three infrequent cutting restriction enzymes (HindIII, EcoRV and EcoRI) followed by melting at $80^{\circ} \mathrm{C}$ failed to show any change in the number of bands compared to un-melted digests (data not shown).

In the absence of an obvious end for the genome from our sequencing experiments we analysed the cumulative GC skew of the sequence (Fig. 4). Skew minima and maxima often represent initiation and termination points of DNA replication in prokaryotes and viruses with a cumulative increase in skew related to the direction of replication and transcription [21]. A clear maximum was observed at about 43000 followed by a sharp change with the minima from 1-8000. This in conjunction with the ORF map and pattern of operons was used to designate $\mathrm{a}+1$ start of the genome (Fig. 4). The cumulative GC skew is consistent with the reading direction of most ORFs and a rolling circle pattern of DNA replication. A single tRNA for phenylalanine (GAA anticodon recognising a UUC codon) was identified using the tRNAscan-SE program. Potential ORFs were assigned using the programs FGENESB and GeneMark.hmm v2.5a (set for prokaryotes); these analyses predicted 63 and 66 ORFs, respectively, encoding polypeptides larger than 30 amino acids. We further analysed the regions upstream and downstream of these predicted ORFs for putative ribosome binding sites and overlapping start and stop codons, and found several additional ORFs. BLAST searches using the amino acid sequences of all predicted ORFs were used to differentiate between possible genes e.g. ORFs 5 and 6 have matches (see below), so putative ORFs in the opposite strand with no BLAST matches have been discounted. By combining all of the data we conclude that BJ1 probably contains 70 ORFs (Fig 4 and Table 1). [If we only count ORFs greater than 60 aa in size then the number of ORFs drops to 55]. Taking the upper estimate of 70 gives an ORF density of $1.65 / \mathrm{kb}$. This is fairly close to the figure of $1.7 \mathrm{ORFs} / \mathrm{kb}$ observed for other archaeal virus genomes (17). The majority of the ORFs have initiation codons of ATG (62) and the rest are GTG (8).

The Shine/Dalgarno sequence from Halobacterium (Halorubrum) saccharovorum 16S rRNA gene sequence (Accession HSU17364), which is the closest phylogenetic match to the phage host was complemented (AGGAGGUGA) and used to search 5-15 bp upstream of each putative start site for the presence of putative ribosome binding sites (RBS). 51 of the 70 ORFs had sequences suggestive of a RBS, (Table 1). One particular stretch of 6 predicted ORFs (ORF43-ORF48) showed no obvious RBSs at all. A lack of a RBS for some genes is not surprising as archaeal transcription/translation is a mosaic of prokaryotic and eukaryotic mechanisms and the first gene of an operon, or a singly transcribed gene often lacks a RBS [22-24].

The majority of the ORFs (59/70) had a low calculated isoelectric point $(\mathrm{pI}<5)$, which is similar to the acidic proteins of halophilic organisms $[15,25]$. Just three small ORFs (less than 74 aa) were predicted to be extremely basic (pI > 10). No ORF larger than 100 aa had a pI above 6.3. 63 ORFs and the tRNA are coded on one strand (designated forward) and 7 are on the reverse strand. One ORF, 30 (13255-14700 bp) overlaps entirely with 


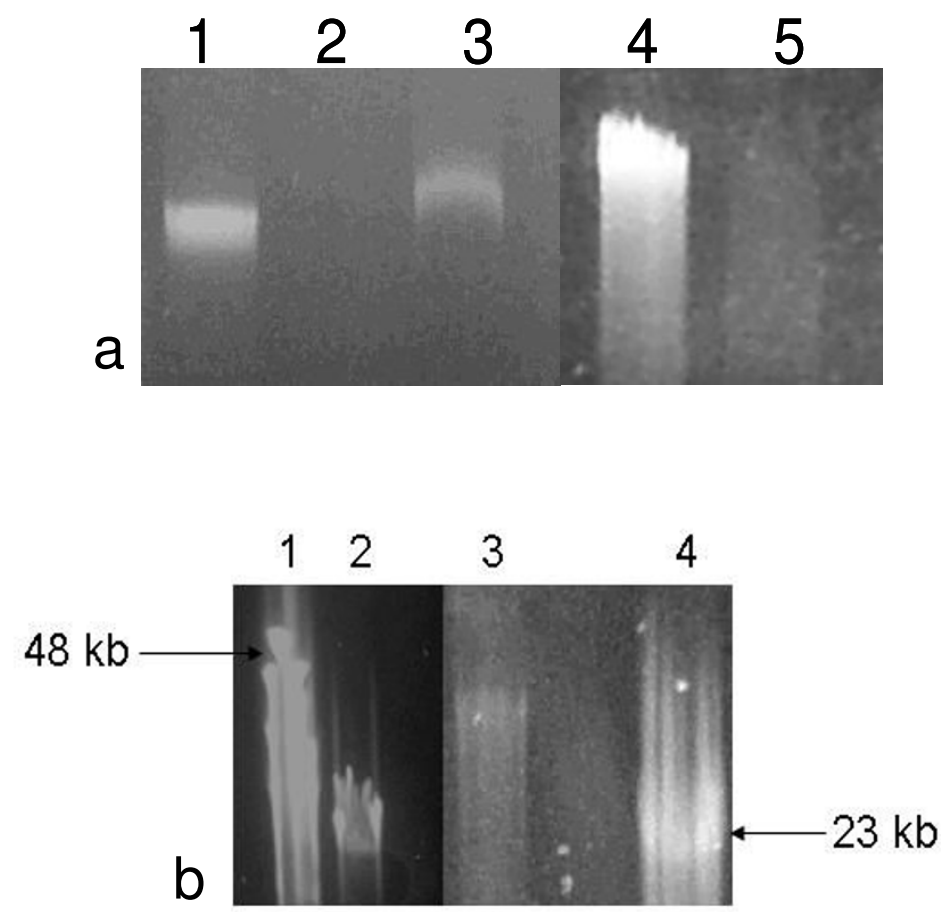

Marker size $(b p)$

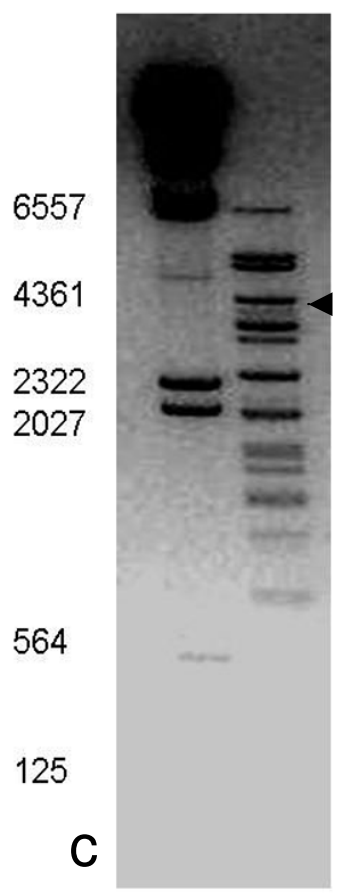

\section{Figure 3}

Panel a. 0.8\% TAE agarose gel showing virus BJI genome sensitivity to nucleases. Lanes I and 4 , undigested controls; Lane 2, DNAse treated; Lane 3 RNase treated; Lane 5, exonuclease III treated. Panel b, I\% agarose 0.5× TBE pulse field gel; lanes I and 4 size markers (kbps), lanes 2 and 3 BJI virus genome. Panel c, BamHI enzyme digest of virus BJI genomic DNA, DNA size markers are shown on the left (kbps). The image has been overexposed to show the smaller bands.

another, ORF31 (13270-14487 bp), running in the opposite direction. It seems probable that both ORFs are coding, ORF30 because it overlaps with the start and stop codons of the ORFs before and after it i.e. 29 and 32, with a good consensus RBS; ORF31 because it shows significant homology to integrases, (see below).

\section{BJI ORF analysis}

Blast $\mathrm{N}$ analysis of the whole virus genome showed significant matches (E $10^{-9}$ to $10^{-4}$ ) to small segments of several haloarchaeal sequences i.e. Natronomonas pharaonis, Halobacterium sp. NRC-1 and Har. marismortui. BlastX analysis identified four regions of the genome having significant matches to data-base proteins either from haloviruses or haloarchaea, discussed below. The putative ORFs were individually analysed using BlastX and BlastP. InterPro was also used to search for functional domains. Using these approaches we were unable to ascribe any match or function to 50 of the 70 ORFs i.e. E values were greater than 0.05 . Of the 20 we could match i.e. E value less than 0.05 , most were to haloarchaeal virus entries or to haloar- chaea. These results are summarised in Table 2. Of these 20, 4 were matches to data-base entries with no identifiable function, i.e.: ORF9, ORF10, ORF17, ORF55 and ORF 24.

The remaining 15 ORFs could have functions tentatively ascribed to them on the basis of amino acid similarity, (Table 2). We place them into three groups. (i) Those probably concerned with DNA replication, gene expression and possibly integration, i.e. ORFs 5, 6, 16, 20, 21, $31,35,39$ and 43 . (ii) Those proteins likely to be involved in virus assembly, i.e. ORFs 48, 49, 50, 52 and 53. (iii) Those proteins with other identifiable functions, i.e. ORF1.

\section{Nucleotide features}

Nine direct repeats were observed greater than 13 nucleotides; the largest was 17 nucleotides, i.e. GGCGGCATCCAACTCGG repeated at positions 34076 and 34120. All of the repeats were located in putative ORFs and we can infer nothing of significance for them. A number of per- 
Table I: Predicted ORFs in virus BJ I

\begin{tabular}{|c|c|c|c|c|c|c|}
\hline ORF & Start & Stop & aa & $\mathrm{Mr}$ & $\mathrm{pl}$ & RBS/distance \\
\hline I & 130 & 990 & 286 & 33 & 4.6 & - \\
\hline 2 & 1146 & 1805 & 219 & 25 & 4.9 & - \\
\hline 3- & 1980 & 2093 & 37 & 3.7 & 8.5 & GGAGGTG-5 \\
\hline 4 & 2207 & 2425 & 72 & 8.1 & 7.0 & - \\
\hline 5- & 2541 & 3191 & 216 & 24 & 4.7 & GAGG-10 \\
\hline 6- & 3178 & 3393 & 71 & 8.2 & 4.3 & - \\
\hline $7 \mathrm{~V}$ & 3547 & 3993 & 148 & 16 & 4.1 & GAG-6 \\
\hline 8 & 3993 & 4463 & 156 & 18 & 4.3 & AGGAGGTGA-8 \\
\hline 9 & 4456 & 4851 & 131 & 15 & 4.2 & AGGAGGTGA-7 \\
\hline 10 & 4844 & 5218 & 124 & 14 & 4.7 & GGAGGT-6 \\
\hline II & 5208 & 5357 & 49 & 5.2 & 3.8 & GAGGTG-8 \\
\hline 12 & 5350 & 5574 & 74 & 8.3 & 4.6 & AGGAGGT-6 \\
\hline 13 & 5571 & 5744 & 57 & 6.1 & 10.4 & GGAGG-5 \\
\hline 14 & $574 I$ & 5986 & 81 & 8.9 & 5.8 & GGAGG-8 \\
\hline 15- & 5998 & 6417 & 139 & 15 & 4.3 & GAGG-7 \\
\hline 16 & 6637 & 7713 & 358 & 40 & 5.0 & AGGTG-9 \\
\hline 17- & 7919 & 8560 & 213 & 24 & 4.3 & AGGA-8 \\
\hline 18 & 8689 & 8949 & 86 & 9.3 & 4.9 & - \\
\hline 19 & 8950 & 9153 & 67 & 7.9 & 5.2 & GGTG-10 \\
\hline 20- & 9159 & 9446 & 95 & 11 & 4.6 & GGAG-4 \\
\hline 21 & 9660 & 10022 & 120 & 14 & 4.6 & GGA-7 \\
\hline 22 & 10022 & 10153 & 43 & 4.6 & 4.0 & GGTG-8 \\
\hline 23 & 10153 & 10890 & 245 & 28 & 3.9 & GGAGG-8 \\
\hline 24 & 10880 & 11806 & 308 & 34 & 4.3 & GGAGG-9 \\
\hline $25 \mathrm{~V}$ & 11803 & 11946 & 47 & 5.2 & 4.1 & GGTGA-7 \\
\hline 26 & 11946 & $1267 \mid$ & 241 & 27 & 4.7 & GGTGA-7 \\
\hline $27 \mathrm{~V}$ & 12668 & 12760 & 30 & 3.3 & 4.5 & GGAGGTG-6 \\
\hline 28 & 12757 & 13092 & 111 & 12.2 & 5.8 & GAGGTGA-5 \\
\hline 29 & 13092 & 13262 & 56 & 6.2 & 3.8 & GGAGG-8 \\
\hline 30 & 13255 & 14700 & 481 & 52 & 6.2 & AGGAGG-6 \\
\hline $31-$ & 13270 & 14487 & 405 & 46 & 5.0 & - \\
\hline 32 & $1470 \mid$ & 14826 & 41 & 4.3 & 4.0 & GGAGGTGA- 9 \\
\hline 33 & 14819 & 15307 & 162 & 18 & 4.6 & GAGGTGA-7 \\
\hline 34 & 15310 & $|553|$ & 73 & 83 & 11.6 & AGGAGGTG-9 \\
\hline 35 & 15489 & 17603 & 704 & 78 & 4.7 & (GAAAA) \\
\hline 36 & 17606 & 18058 & 150 & 17 & 4.4 & GGAGG-9 \\
\hline ORF & Start & Stop & aa & $\mathrm{Mr}$ & pl & RBS/distance \\
\hline 37 & 18055 & 18519 & 154 & 18 & 4.3 & (GGGGG) \\
\hline $38 \mathrm{~V}$ & 18512 & 18817 & 101 & 11 & 5.0 & GAGGTG-8 \\
\hline $39 \mathrm{~V}$ & 18814 & 19074 & 86 & 9.9 & 6.1 & GAGGTG-9 \\
\hline $40 \mathrm{~V}$ & $1907 \mid$ & 19241 & 56 & 5.9 & 10.3 & GGAGG-8 \\
\hline $41 \mathrm{~V}$ & 19129 & 19806 & 225 & 26 & 6.3 & - \\
\hline 42 & 19803 & 19982 & 59 & 6.4 & 4.0 & GAGGTG-6 \\
\hline tRNA & 19973 & 20046 & - & - & - & - \\
\hline 43 & 20365 & 21843 & 492 & 55 & 4.9 & - \\
\hline 44 & 21840 & 21998 & 52 & 5.9 & 4.3 & - \\
\hline 45 & 22001 & 22111 & 36 & 3.9 & 4.8 & - \\
\hline 46 & 22108 & 22416 & 102 & 11 & 4.3 & - \\
\hline 47 & 22416 & 22577 & 53 & 6.1 & 4.2 & - \\
\hline 48 & 22574 & 23083 & 169 & 19 & 4.3 & - \\
\hline 49 & 23080 & 24423 & 447 & 50 & 4.9 & GAGG-8 \\
\hline 50 & 24427 & 26382 & 651 & 73 & 4.5 & - \\
\hline 51 & $2646 I$ & 26586 & 41 & 4.4 & 4.4 & GAG-9 \\
\hline 52 & 26590 & 27933 & 447 & 47. & 3.9 & AGGAGG-9 \\
\hline 53 & 27949 & 29031 & 360 & 40 & 4.2 & GTGA-8 \\
\hline 54 & 29040 & 29219 & 59 & 6.4 & 3.8 & GAGGTGA-4 \\
\hline 55 & 29222 & 29572 & 116 & 12 & 3.9 & - \\
\hline 56 & 29576 & 30451 & 291 & 33 & 4.6 & GGAGG-9 \\
\hline 57 & 30444 & 30761 & 105 & 11 & 4.1 & - \\
\hline
\end{tabular}


Table I: Predicted ORFs in virus BJI (Continued)

\begin{tabular}{|c|c|c|c|c|c|c|}
\hline 58 & 30758 & 31210 & 150 & 17 & 4.8 & AGG-10 \\
\hline 59 & 31207 & 31734 & 175 & 20 & 4.5 & GGAGGT-5 \\
\hline $60 \mathrm{~V}$ & 31766 & 32680 & 304 & 32 & 3.8 & GAGGTGA-7 \\
\hline 61 & 32680 & 33177 & 165 & 18 & 4.0 & AGGAGGTGA-8 \\
\hline 62 & 33281 & 34408 & 375 & 38 & 4.1 & - \\
\hline 63 & 34444 & 34731 & 95 & 10 & 4.8 & - \\
\hline 64 & 34771 & 35439 & 222 & 24 & 4.0 & - \\
\hline 65 & 35446 & 36633 & 395 & 42 & 4.1 & TGA-7 \\
\hline 66 & 36634 & 38226 & 530 & 52 & 3.7 & AGGAGGTG-10 \\
\hline 67 & 38229 & 40979 & 916 & 100 & 4.0 & GGAGGTG-I5 \\
\hline 68 & 41059 & 41400 & 113 & 12 & 3.8 & GGAG-6 \\
\hline 69 & $4 \mid 403$ & 41843 & 146 & 16 & 4.6 & AGGTG-9 \\
\hline 70 & 41840 & 42151 & 103 & 11 & 3.9 & GGTGA-4 \\
\hline
\end{tabular}

Orfs are in the forward direction unless indicated by a -ve sign. $v$ indicates a valine start. aa indicates the number of amino acids. Mr is the molecular mass $\times 10^{-3}$, rounded to the nearest 100 . pl is the isoelectric point rounded to one decimal place. rbs/distance is the ribosome binding site sequence and its distance from the start codon.

fect and imperfect inverted repeat/stemloop structures were identified, often having loops $100 \mathrm{~s}-1000 \mathrm{~s}$ of nucleotides in size. One perfect palindrome is located at nucleotides ${ }_{14226}$ GTCCGCTGGA/TCCAGCGGAC ${ }_{14247}$ in ORF31, the putative integrase gene. Another palindrome separated by 3 nucleotides (lower case) is ${ }_{42048}$ ACTATCCGACtggGTCGGATAGT 42070 ; again both are present in putative ORFs and their significance is unclear although the last palindrome is located 209 nucleotides from the 3' end of the genome. The BJ1 genome has a low incidence of CTAG and GATC sequences, just three of each of these palindromes being present. This incidence is low, both compared to the statistically expected incidence, (every 256 base pairs) and compared to the related tetramers CGAG and GCTC which were both found 36 times. CTAG and GATC sequences appear to be selected against by many haloviruses e.g. these palindromes are absent from the genomes of HF1, HF2, His2 and SH1 [6]. This selection pressure is thought to be due to the avoidance of restriction-modification systems in the host cells [26], and there is evidence that CTAG and GATC palindromes are used by haloarchaeal systems [27,28].

\section{Sequence heterogeneity}

BamHI digests of virion DNA gave rise to a fragment of about $3.5 \mathrm{~kb}$, as judged by agarose gel electrophoresis, present in sub-stoichiometric amounts relative to the other bands, indicated by the black arrow in Fig 3c. This was fully sequenced and found not to fit into our genome assembly. Primers derived from this sequence were used with virus sequence primers and virus genomic DNA as a template. Products were observed with primers derived from the 3' end of ORF 32, suggesting that a minor subfraction of virion DNA did contain this BamHI fragment. Sequencing showed that the site of insertion was at nucleotide 14790 in ORF 32 and showed that this part of ORF 32 was rich in CGX repeats, (Table 3 ). We have not yet been unable to derive PCR products defining either the location or 5 ' end of the insertion/substitution. Instead we have primer walked out from the defined 3 ' end of the insertion. $\sim 8.7 \mathrm{~kb}$ of sequence has been determined [EMBL: AM491333] having a $\mathrm{G}+\mathrm{C}$ content of $72.6 \mathrm{~mol} \%$, notably higher than the $64 \mathrm{~mol} \%$ determined for the rest of the virus genome and close to that reported for Hrr. saccharovorum (71 mol\%). Predicted ORFs have much higher homologies to known haloarchaeal proteins than the other viral ORFs, (Table 3). We think it most likely this sequence is derived from the host genomic DNA due to an integration/excision event.

\section{Discussion}

Morphological criteria used for virus classification is outlined by the International Committee for Taxonomy of Viruses [7]. Virus BJ1 is an icosahedral head/tailed virus and as such is assigned to the order Caudovirales with examples infecting members of both the domains Bacteria and Archaea. BJ1 can also be assigned to the Bradley classification group $\mathrm{B}$ and might tentatively be assigned to the family Siphoviridae due to the apparent absence of a contractile tail, base plate and tail fibres and the presence of striations in the tail fibre. If we assume that this classification is phylogenetically justified then it could indicate that the Caudovirales originated before the divergence of the Bacteria and Archaea [29]. An alternative explanation is that the Caudovirales originally infected members of the domain Bacteria but that horizontal gene exchange from mesophilic Bacteria to the Archaea and the subsequent stabilisation of these genes in the Archaea allowed the Caudovirales to spread into the domain Archaea [Certainly we have detected diverse bacterial populations in the water of Lake Bagaejinnor, SH unpublished] [9].

As described in the Introduction, very few viruses infecting the domain Archaea have been described and as yet we have little idea as to the extent of virus diversity in this domain. The virus we describe here may not be a common or dominant member of the virus community infecting haloarchaea in saline waters. We screened for lytic virus 


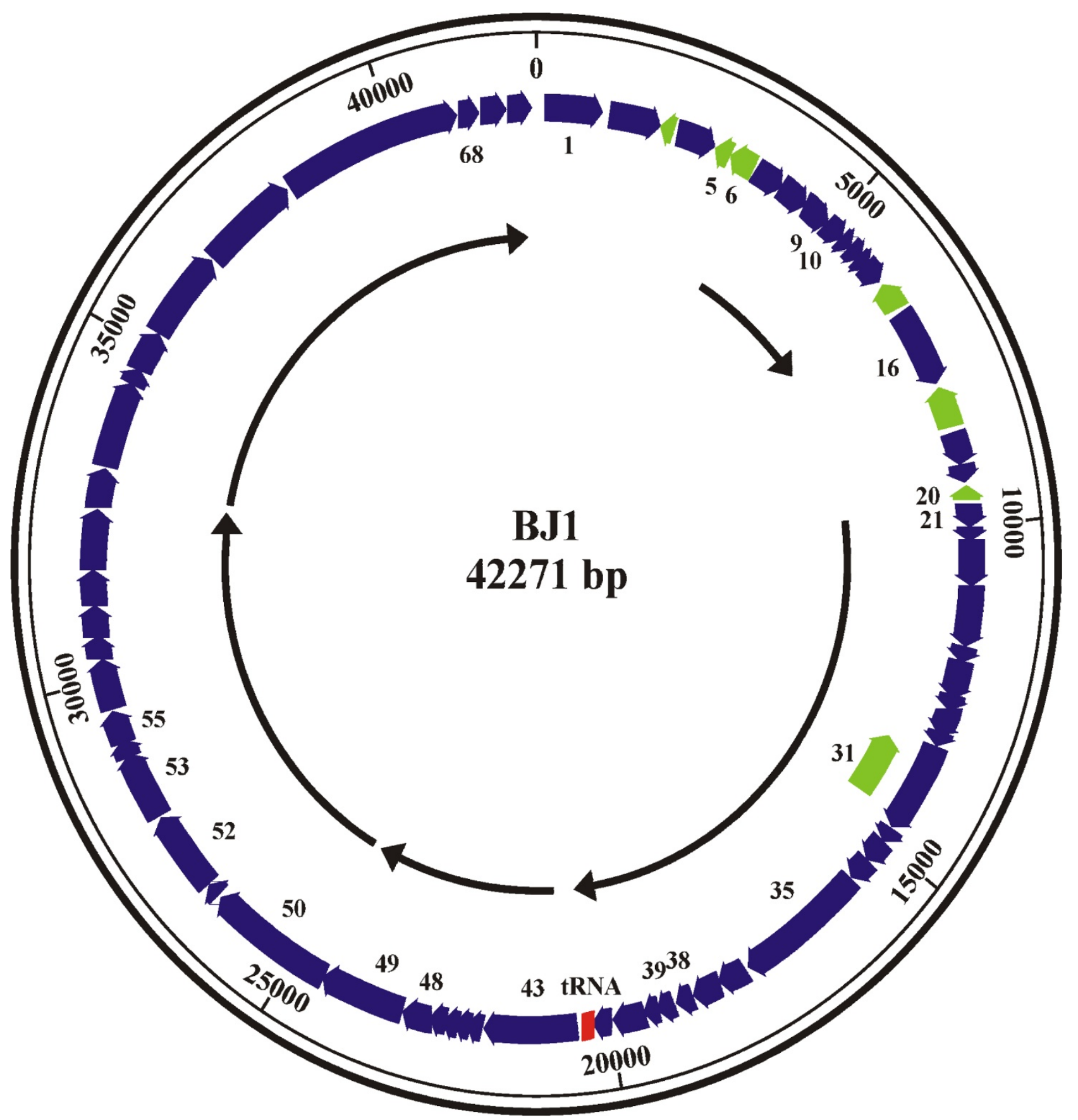

Figure 4

Top panel. Diagram of the BJI genome drawn in a circular form. The major features are shown including the predicted ORFs, blue arrows in the forward direction, green arrows in the reverse. The tRNA gene is in red. ORFs mentioned in the text are numbered. The outer scale bar is in base pairs. The inner curved arrows indicate entirely hypothetical operons. The bottom panel shows the cumulative GC skew.

particles forming plaques on archaeal lawns. These requirements for host culturability, good lawn formation and plaque formation are probably extremely restrictive.
As pointed out by others, there is a genuine need to develop other isolation and culture techniques to study both the dominant virus populations and the true extent 
Table 2: BJI ORFs with identifiable BlastX matches to data base entries.

\begin{tabular}{|c|c|}
\hline ORF & Homologs (\% Identity) \\
\hline 9 & $\begin{array}{l}59 \% \text { similarity }\left(\mathrm{E} 10^{-8}\right) \text { to ORF58 halovirus } \phi \mathrm{Ch} \mathrm{I} \\
\text { (AAM88732) }\end{array}$ \\
\hline 10 & $\begin{array}{l}\text { 54\% similarity }\left(\mathrm{EI}^{-5}\right) \text { to protein Haloquadratum walsbyi } \\
\text { (CAJ52235) }\end{array}$ \\
\hline 17 & $\begin{array}{l}\text { similarity }(\mathrm{E} \mathrm{I0-13}) \text { to protein from Natronomonas pharaonis } \\
(\mathrm{CR} 936257.1)\end{array}$ \\
\hline 55 & similarity $\left(\mathrm{E} 10^{-7}\right)$ to a protein of $\phi \mathrm{ChI}$ (NP 665930.I) \\
\hline 24 & $\begin{array}{l}\text { No significant match to any described protein. InterPro } \\
\text { suggests DNA binding protein }\end{array}$ \\
\hline 5 & $\begin{array}{l}\text { similarity }\left(E 10^{-3}\right) \text { to bacterial proteins with DnaJ domain; } \\
\text { role in DNA replication? }\end{array}$ \\
\hline 6 & $\begin{array}{l}65 \% \text { similarity }\left(\mathrm{E} 10^{-6}\right) \text { to protein (AAG20925) of } \\
\text { Halobacterium sp. NRC-I. A metal regulated homodimeric } \\
\text { repressor with a 'winged helix' DNA binding domain }\end{array}$ \\
\hline 16 & $\begin{array}{l}60 \% \text { similarity }\left(\mathrm{E} 1 \mathrm{I}^{-67}\right) \text { to a Har. marismortui protein } \\
\text { YP_I } 36906 \text {; member of the ORCI/CDC-6 superfamily of } \\
\text { NTPases involved in DNA replication }\end{array}$ \\
\hline 20 & $\begin{array}{l}54 \% \text { similarity }\left(\mathrm{E} 10^{-13}\right) \text { to halovirus } \phi \mathrm{HI} \text { repressor } \\
\text { protein(AAV47 I98.1) with a winged helix DNA binding } \\
\text { domain }\end{array}$ \\
\hline 21 & $\begin{array}{l}66 \% \text { similarity }\left(\mathrm{E} \mid 0^{-17}\right) \text { to the Hqr. walsbyi PadR } \\
\text { transcriptional regulator (CAJ5I359.1) }\end{array}$ \\
\hline 31 & $\begin{array}{l}\text { similarity is to a Har. marismortui phage integrase }\left(\mathrm{E} \mid 0^{-66}\right) \\
45 \% \text { ID (AAV } 47153 \text { the } \lambda \text { bacteriophage recombinase } \\
\text { family, pfam } 00589\end{array}$ \\
\hline 35 & $\begin{array}{l}\text { DNA helicase? } 62 \% \text { similarity }\left(E 10^{-128}\right) \text { to Har. marismortui } \\
\text { protein (AAV47/42) of the Cdc- } 46 / \mathrm{Mcm} \text { family of DNA } \\
\text { dependent ATPases. }\end{array}$ \\
\hline 39 & $\begin{array}{l}68 \% \text { similarity }(\mathrm{E} 0.05) \text { to ArsR-like transcriptional } \\
\text { regulator (CAJ5I } 299) \text { from Hqr. Walsbyi ( } 92 \text { amino acids } \\
\text { long); the similarity being from amino acids I5-68 in } \\
\text { ORF39 with } 20-72 \text { in CAJ5 } 1299\end{array}$ \\
\hline 43 & $\begin{array}{l}56 \% \text { similarity }\left(\mathrm{E} \mid \mathrm{O}^{-37}\right) \text {, to halovirus } \mathrm{HFI} \text { protein } \\
\text { (AAO6I337.I) which may be a YonJ like, small subunit of } \\
\text { the DNA polymerase, (COGI3II) }\end{array}$ \\
\hline 48 & $\begin{array}{l}\text { 54\% similarity to Listonella pelagia phage phiHSIC small } \\
\text { terminase subunit (YP_224235.I }\end{array}$ \\
\hline 49 & $\begin{array}{l}43 \% \text { similarity }(\mathrm{E} 0.0 \mathrm{I}) \text { to Streptococcus pneumoniae } \\
\text { bacteriophage EJ-I large terminase (CAE82I II) }\end{array}$ \\
\hline 50 & $\begin{array}{l}54 \% \text { similarity }\left(\mathrm{E} \mid \mathrm{O}^{-77}\right) \text { to the putative portal protein } \\
\left(\mathrm{NP} \_665924\right) \text { of } N a b . \text { magadii virus } \phi \mathrm{Ch} \mathrm{I} \text {. }\end{array}$ \\
\hline 52 & $\begin{array}{l}49 \% \text { similarity }\left(\mathrm{E} \mathrm{I}^{-13}\right) \text { to the capsid protein gpD } \\
\text { (AAM88683) of halovirus } \phi \mathrm{ChI}\end{array}$ \\
\hline 53 & $\begin{array}{l}48 \% \text { similarity }\left(\mathrm{E} \mid 0^{-29}\right) \text { to } \mathrm{hp} 32(\mathrm{CAA} 56442) \text { of } \mathrm{Hbt} \text {. } \\
\text { salinarum virus } \phi \mathrm{H} \text { and } 47 \% \text { similarity }\left(\mathrm{E} \mathrm{IO} 0^{-24}\right) \text { to the capsid } \\
\text { protein gpE (AAG32I63) of halovirus } \phi C h \mathrm{C} I\end{array}$ \\
\hline 51 & $\begin{array}{l}51 \% \text { similarity }\left(E_{10} 0^{-15}\right) \text { to Enterococcus faecium glycosyl } \\
\text { transferase (EAN I092I). LPS biosynthesis protein. }\end{array}$ \\
\hline
\end{tabular}

of archaeal virus variation in samples such as these - perhaps using a combination of electron microscopy and metagenomic sequence studies.

The GC content of BJ1 at $65 \mathrm{~mol} \%$ is quite close to that reported for Hrr. spp aidingense, lacusprofundi and saccharovorum, varying from about $63-71 \mathrm{~mol} \%[19,20]$. The host strain for BJ1 clearly belongs to the genus Halorubrum having 98\% 16SrRNA gene sequence identity to these Halorubrum species. Its precise taxonomic relationship to these species, in particular if it belongs to a new Halorubrum species is the subject of current studies.

Of the ORFs identified in BJ1 described in the results, all of the statistically significant matches are recorded, (Table $2)$. Six of the ORFs $(9,20,50,52,53,55)$ are most closely related to the haloarchaeal temperate, isometric head/ contractile tail viruses $\phi \mathrm{Ch} 1$ [13] and the intensively studied, $\phi \mathrm{H}$ [30]. These two viruses are closely related to each other, the completed genome of $\phi \mathrm{Ch} 1$ shows $97 \%$ homology to the genome of $\phi \mathrm{H}$, which is about $60 \%$ complete. ORF 43 is most closely related to a gene from the haloarchaeal isometric head/contractile tail virus HF1. There are no similarities with the ORFs from either the spindle (His1, His2) or icosahedral (SH1) shaped haloarchaeal viruses described in the Introduction. The most significant matches were ORFs $16,31,35$, which are almost certainly the origin of replication complex, integrase and helicase functions respectively of the virus, having highly significant matches to full length proteins in Har. marismortui. ORF50 was also closely related to the putative portal protein (NP_665924) of Nab. magadii virus $\phi$ Ch1.

Speculatively, almost all ORFs are in the forward strand in the same direction consistent with a rolling circle mechanism of DNA replication. The 7 ORFs on the reverse strand including the integrase may be poorly expressed. A few ORFs had GTG starts (but with good RBS sequences) and the other ORFs lacked RBS sequences altogether, presumably both coding features control/reduce expression levels. The fact that putative Int gene is coded for on the minor strand with no RBS and that it overlaps with ORF 30 on the major strand may indicate that its expression is tightly controlled; perhaps most infections are lytic with a small proportion of lysogenic events. The suggestion of operons indicated in Fig 4 is also entirely speculative and based on the presence of overlapping stop and start signals, one run of ORFs from 43-48 has no RBS at all. Proteins with putative functions involved in DNA replication and transcription are found in ORFs 1-43, putative structural proteins are found after ORF48 consistent with early and late expression of operons.

Although BJ1 stocks are clonal in origin, the genomic DNA preparation is obviously and necessarily derived from a virus pool. Genome sequence projects often therefore give rise to heterogeneous sequences. We found one substantial region of heterogeneity in ORF 32 at nucleotide 14790 involving either a large insertion or more probably a substitution event (since terminally redundant virus genomes usually package genomes in a 'head full' mechanism). To distinguish between these possibilities 
Table 3: Predicted ORFs in the sequence inserted into ORF 32 and their highest BlastX matches. Nucleotide numbering is from the $5^{\prime}$ end of the insertion sequence; nucleotide 8685 corresponds to nucleotide I4790 in the BJI genomic sequence. The sequence at the site of insertion was tgctcggtcgtcaa/CGACGCCGACGACGGCGA; lower case variant, upper case BJI ORF 32. Orfs are in the forward direction with respect to the virus genome unless indicated by a - sign. * indicates a truncated ORF because of incomplete sequencing (VI0) or the insertion event itself (VI and ORF32) aa indicates the number of amino acids.

\begin{tabular}{lllll}
\hline ORF & \multicolumn{2}{c}{ Position } & Size & Homologs (\% Identity) \\
\hline & Start & Stop & (aa) & \\
\hline VI0* & 2 & 277 & $*$ & $67 \%$ - ornithine cyclodeaminase Natronomonas pharaonis DSM 2160 \\
V9- & 749 & 351 & 132 & $36 \%$ - hypothetical protein VNG6157H Halobacterium sp. NRC-I \\
V8- & 1910 & 843 & 355 & $70 \%$ - cell division protein pelota Natronomonas pharaonis DSM 2160. \\
V7- & 3051 & 1936 & 371 & $28 \%$ - hypothetical protein NP4342A Natronomonas pharaonis \\
V6 & 3346 & 3753 & 135 & $38 \%$ - hypothetical protein rrnAC2062 Haloarcula marismortui \\
V5 & 3912 & 4685 & 257 & $38 \%$ - Alpha/beta hydrolase fold protein Ralstonia eutropha JMPI34 \\
V4 & 4747 & 5058 & 103 & $75 \%$ - hypothetical protein HQ2797A Haloquadratum walsbyi DSM I6790 \\
V3- & 7408 & 5900 & 502 & $73 \%$ - RtcB-like protein I Natronomonas pharaonis DSM 2160 \\
V2- & 7934 & 7503 & 143 & $61 \%$ - hypothetical protein NP3986A Natronomonas pharaonis DSM 2160 \\
VI* & 8326 & 8684 & $119 *$ & $64 \%$ - 3-hydroxy-3-methylglutaryl-coenzyme A reductase (HMG-CoA reductase) Haloferax volcanii \\
$32 *$ & 8685 & 9059 & $*$ & $100 \%$ Phage BJI hypothetical protein \\
\hline
\end{tabular}

requires more sequencing. The variant sequence probably involves the acquisition of host derived DNA since the GC content is higher $(72.6 \%)$ than that of the virus $(64.8 \%)$ and close to that reported for Hrr. saccharovorum (71\%). Obviously this insertion/substitution has taken place about 300 nucleotides away from the putative integrase gene. The integrase gene in viruses is often the site of insertion as well. We speculate that this variant sequence in the virus population is the result of an integration/excision event (possibly aberrant) during the virus infection to prepare genomic DNA. This may indicate that BJ1 is a lysogenic virus; plaques were certainly turbid consistent with this suggestion but further experiments will be required to prove it. Whether the virus population with this variant sequence is viable will also require further studies. Certainly virus populations with insertions and or substantial genomic deletions can be viable or at least rescued by functional virus genomes.

Many interesting features remain to be discovered about the $\mathrm{BJ} 1$ virus. Optimal growth conditions for this virus need to be established and its host range determined. This will facilitate studies on its environmental stability, patterns of transcription, protein functions, lysogenic potential and the viability of the variant virus. Assignment of protein functions to ORFs which cannot be assigned any function based on sequence identity is probably easier using a virus as a model than any other genome. A systematic effort on this front will reduce the number of unclassified ORFs that metagenomic and archaeal sequencing projects so often throw up.

\section{Methods}

\section{Cultivation of prokaryotes from environmental samples}

Isolates were grown on a modified Classic Halophile Medium (mCHM) broth, [31]. This was made in two components; component 1 contains $1 \%(\mathrm{w} / \mathrm{v})$ yeast extract, $0.75 \%(\mathrm{w} / \mathrm{v})$ casamino acids, $0.248 \%(\mathrm{w} / \mathrm{v}) \mathrm{KCl}$ and $0.3 \%(\mathrm{w} / \mathrm{v})$ trisodium citrate; component 2 contains $0.162 \%$ (w/v) $\mathrm{Na}_{2} \mathrm{~B}_{4} \mathrm{O}_{7}, 0.084 \%$ (w/v) NaBr, $7.116 \%$ (w/ v) $\mathrm{MgCl}_{2} .7 \mathrm{H}_{2} \mathrm{O}, 13 \%(\mathrm{w} / \mathrm{v}) \mathrm{NaCl}, 4.56 \%(\mathrm{w} / \mathrm{v}) \mathrm{Na}_{2} \mathrm{SO}_{4}$, $0.062 \%(\mathrm{w} / \mathrm{v}) \mathrm{NaHCO}_{3}$ and $0.036 \%(\mathrm{w} / \mathrm{v}) \mathrm{Na}_{2} \mathrm{CO}_{3}, \mathrm{pH}$ 8.0. Both components were autoclaved separately and mixed once cooled to $60^{\circ} \mathrm{C}$, then stored at room temperature. $2 \%(\mathrm{w} / \mathrm{v})$ agar was added to component 1 if required to make mCHM agar plates, while $0.7 \%(\mathrm{w} / \mathrm{v})$ agar was added to component 1 to make soft top agar. Prokaryotes were cultivated from brine, salt or sediment samples. Brine was filtered on site through sterile $0.45 \mu \mathrm{m}$ membrane filters in a $250 \mathrm{ml}$ capacity polycarbonate filter unit (Sartorius) using a Nalgene hand pump until flow stopped. Membrane filters were immediately placed in cold sterile stabilisation buffer $(10 \mathrm{mM}$ Tris- $\mathrm{HCl}, \mathrm{pH} 8.0$, $1 \mathrm{mM}$ EDTA, $2 \mathrm{M} \mathrm{NaCl}$ ) and agitated to resuspend the cells. Filtered waters were placed in sterile falcon tubes. Samples were placed immediately on ice until they could be stored at $-20^{\circ} \mathrm{C}$, usually within 6 hours of collection. Either, cell suspensions from agitated filters were serially diluted and plated onto mCHM agar plates, or about 0.5 $\mathrm{g}$ sediment and salt crust was resuspended in $0.5 \mathrm{ml}$ of mCHM and serial dilutions plated onto the mCHM agar plates. These were incubated for two months at $37^{\circ} \mathrm{C}$ and were periodically checked for the appearance of new colonies which were picked and grown on fresh plates. Subculturing was continued on the same medium until purity was achieved. Isolated colonies were then grown in 
mCHM broth to an $\mathrm{OD}_{695}$ of 2 to 4 , and maintained on sterile beads at $-80^{\circ} \mathrm{C}$ for long-term storage in mCHM broth with $30 \%(\mathrm{v} / \mathrm{v})$ sterile glycerol.

\section{Identification of haloarchaeal isolates by I6S rRNA gene sequencing}

Pure cultures, see above, were lysed in $100 \mu$ l nanopure water and boiled for $10 \mathrm{~min}$. Cell debris was pelleted by centrifugation at $13000 \times \mathrm{g}$ for $10 \mathrm{~min}$. $1 \mu \mathrm{l}$ cell lysate was used in a PCR reaction containing $(75 \mathrm{mM}$ Tris- $\mathrm{HCl}, \mathrm{pH}$ 8.8, $20 \mathrm{mM}\left(\mathrm{NH}_{4}\right)_{2} \mathrm{SO}_{4}, 0.01 \%(\mathrm{v} / \mathrm{v})$ Tween 20$), 0.2 \mathrm{mM}$ dNTPs, $3 \mathrm{mM} \mathrm{MgCl}_{2}, 20$ pmol forward primer, $20 \mathrm{pmol}$ reverse primer, 2.5 U Taq polymerase and nanopure water to a final volume of $50 \mu \mathrm{l}$. To amplify the $16 \mathrm{~S}$ rRNA genes, the Archaeal domain specific primer 27Fa, 5'-TCY GGT TGA TCC TGS CGG-3', [32] and rP1 5'-ACG GHT ACC TTG TTA CGA CTT-3', [33] were used. Reaction conditions were: $95^{\circ} \mathrm{C}$ for $2 \mathrm{~min}$, followed by 30 cycles of $95^{\circ} \mathrm{C}$ for $30 \mathrm{~s}, 50^{\circ} \mathrm{C}$ for $40 \mathrm{~s}$ and $72^{\circ} \mathrm{C}$ for $2 \mathrm{~min}$, followed by 10 min extension time at $72^{\circ} \mathrm{C}$. PCR products were purified using the QIAquick PCR Purification Kit (Qiagen) and stored at $-20^{\circ} \mathrm{C}$ until required. DNA sequencing, also see below, was done by Lark Technologies, Cambridge UK using 27Fa and rP1 primers described above (corresponding to nucleotides 27-1492 with E. coli as the reference sequence). The DNA sequences were analysed using the BLASTN homology search program [34], which is available at the National Centre for Biotechnology Information to identify close matches.

Strains were placed on a phylogenetic tree using Molecular Evolutionary Genetics Analysis (MEGA) version 3.1 [35], using the Jukes and Cantor nucleotide substitution model for sequence alignment and the Neighbour-Joining method of tree inference. The support for each node was determined by assembling a consensus tree of 500 bootstrap replicates.

\section{Isolation of haloarchaeal virus by plaque assays}

Haloarchaeal strains identified as described above were grown in soft top agar. mCHM bottom agar plates were overlaid with mCHM soft top agar containing $0.75 \%$ (w/ v) agar, kept molten in a $55^{\circ} \mathrm{C}$ water bath until required. $300 \mu \mathrm{l}$ of the haloarchaeal strain (OD approximately 0.2 at $695 \mathrm{~nm}$, avoiding absorbance by the archaeal pigments) was added to $3 \mathrm{ml}$ agar cooled to approximately $50^{\circ} \mathrm{C}$ and mixed. This was immediately poured on top of the bottom agar and left to set. The plates were carefully inverted and incubated in a sealed bag at $37^{\circ} \mathrm{C}$ for a week or longer. If good lawns were formed the strain was used to isolate haloarchaeal virus as follows: $10 \mu \mathrm{l}$ of Bagaejinnor lake water passed through both a 0.45 and $0.22 \mu \mathrm{m}$ filter (both from Millipore) was added to $1 \mathrm{ml}$ cell culture and incubated at $37^{\circ} \mathrm{C}$ in an orbital shaker at $150 \mathrm{rpm}$ overnight. The culture was plated in soft top agar as described and the resulting lawns checked for the appearance of lytic plaques. Single plaques selected for purification were picked with a sterile toothpick. Virus particles were then resuspended in $100 \mu \mathrm{lmCHM}$ broth; this was then used to infect the host as previously described. This process of plaque purification was repeated twice to ensure that the virus samples were pure. Virus particles remained stable in $\mathrm{mCHM}$ broth when placed at $4{ }^{\circ} \mathrm{C}$ for at least 1 year.

\section{Transmission electron microscopy}

$5 \mu \mathrm{l}$ of the virus sample was adsorbed onto glow discharged, carbon coated pioloform grids and fixed in glutaraldehyde vapour for $3 \mathrm{~min}$. Excess sample was blotted from the grid using filter paper. Salts were removed by washing with distilled water. The sample was visualised by negative staining using $1 \%(\mathrm{w} / \mathrm{w})$ uranyl acetate and viewed on a JEOL 1220 transmission electron microscope fitted with a SIS Megaview III digital camera system. Captured Images were viewed and analysed using the Image J program [36].

\section{Viral nucleic acid extraction}

Attempts to purify virus nucleic acid from infected liquid cultures were unsuccessful. Accordingly $30 \mu \mathrm{l}$ of virus stock $\left(\sim 10^{6} \mathrm{pfu} / \mathrm{ml}\right)$ were added to $300 \mu \mathrm{l}$ of host cell culture (OD approximately 0.2 at $695 \mathrm{~nm}$ ). Virus particles were left to adsorb onto the host cells for $15 \mathrm{~min}$ at room temperature, mixed with soft top agar and poured and incubated as described above to give agar plates with a high density of virus plaques. $0.5 \mathrm{ml}$ halovirus diluent [60\% (v/v) of a salt solution containing; $0.3 \%(\mathrm{w} / \mathrm{v}) \mathrm{KCl}$, $0.162 \%$ (w/v) $\mathrm{Na}_{2} \mathrm{~B}_{4} \mathrm{O}_{7}, 0.084 \%$ (w/v) NaBr, $7.116 \%$ (w/ v) $\mathrm{MgCl}_{2} .7 \mathrm{H}_{2} \mathrm{O}, 13 \%(\mathrm{w} / \mathrm{v}) \mathrm{NaCl}, 4.56 \%(\mathrm{w} / \mathrm{v}) \mathrm{Na}_{2} \mathrm{SO}_{4}$ $0.062 \%(\mathrm{w} / \mathrm{v}) \mathrm{NaHCO}_{3}$ and $0.036 \%(\mathrm{w} / \mathrm{v}) \mathrm{Na}_{2} \mathrm{CO}_{3} ; 29 \%$ (v/v) $\mathrm{H}_{2} \mathrm{O} ; 1 \%(\mathrm{v} / \mathrm{v}) 1 \mathrm{M}$ Tris $\mathrm{pH} 7.2 ; 10 \%(\mathrm{v} / \mathrm{v})$ glycerol] was added to each plate and the virus harvested by scraping off the soft top agar and homogenising by vortexing for $30 \mathrm{~s}$. Agar and cell debris was pelleted by centrifugation at $10000 \mathrm{rpm}$ for 20 mins. The supernatant was transferred to a fresh clean tube. To increase the yield of virus particles, the pellet was resuspended in $2 \mathrm{ml}$ halovirus diluent and the previous steps of homogenisation and centrifugation were repeated. Combined supernatants were passed through a $0.45 \mu \mathrm{m}$ filter and then a $0.22 \mu \mathrm{m}$ filter to further remove agar and cell debris. To remove any exogenous non-virus nucleic acids DNase I and RNase A were each added to a final concentration of $1 \mu \mathrm{g} / \mathrm{ml}$ and the sample left at room temperature for $30 \mathrm{~min}$.

Virus particles were precipitated by the addition of $1 / 8$ volume polyethylene glycol (PEG) 6000 solution $(2.5 \mathrm{M}$ $\mathrm{NaCl}, 20 \%$ (w/v) PEG 6000) and left to incubate for 15 min at room temperature. Virus particles were pelleted by centrifugation at $13000 \times \mathrm{g}$ for $5 \mathrm{~min}$. The supernatant 
was carefully removed and the pellet resuspended in 100 $\mu \mathrm{l}$ phosphate buffered saline $(0.8 \% \mathrm{w} / \mathrm{v} \mathrm{NaCl}, 0.121 \% \mathrm{w} /$ $\mathrm{v} \mathrm{K} \mathrm{HPO}_{4}$ and $0.034 \% \mathrm{w} / \mathrm{v} \mathrm{KH}_{2} \mathrm{PO}_{4}$ ). To extract genomic nucleic acid from the virus, the pellet was mixed with an equal volume of phenol chloroform and centrifuged for $30 \mathrm{~s}$. The top nucleic acid containing aqueous layer was transferred to a fresh tube. Excess phenol chloroform was removed by ether extraction. The nucleic acid was ethanol precipitated, redissolved in $20 \mu \mathrm{l}$ Tris-EDTA, pH 8.0 and left to rehydrate at $4^{\circ} \mathrm{C}$ overnight. An extraction from 20 plates typically yielded $1-2 \mu$ g nucleic acid.

\section{Genome characterisation and sequencing}

$1 \mu \mathrm{g}$ virus nucleic acid was treated with either excess DNase I (NEB), RNase A (Sigma) or Exonuclease III (NEB) in the manufacturers reaction buffer and incubated at $37^{\circ} \mathrm{C}$ for $10 \mathrm{~min}, 60 \mathrm{~min}$ or $30 \mathrm{~min}$ respectively. Reactions were electrophoresed on Tris-Acetate-EDTA (TAE) agarose gels and stained with SYBR green. Viral nucleic acids were ran on a $1 \%$ agarose pulse field gel (BioRad) in $0.5 \times$ TBE buffer at $14^{\circ} \mathrm{C}$ in a CHEF DR-II apparatus (BioRad). The run time was $22 \mathrm{~h}$ with a voltage gradient of 6 $\mathrm{V} / \mathrm{cm}$ and a linearly ramped pulse time of 50 to $90 \mathrm{~s}$ at an angle of $120^{\circ}$.

BJ1 genomic DNA was digested with BamHI (giving approximately 20 fragments ranging in size from $100 \mathrm{bp}$ to $5 \mathrm{kbp}$, and cloned into BamHI-digested pUC18NotI vector [37]. Resulting clones were sequenced using vectorspecific oligonucleotide primers pUCF, 5'-GTTTTCCCAGTCACGACGTTG-3' and pUCR, 5'-CACAGGAAACAG CTATGACC-3'; these sequences were used to design further primers to primer walk across the clones. The high $\mathrm{G}+\mathrm{C}$ content ( $65 \mathrm{~mol} \%)$ of the initial sequences was used to identify restriction enzymes that would likely cut the phage genome to give smaller (on average 500-1000 bp) fragments. Secondary libraries of SstI and XhoI fragments were created in pUC18NotI and representative clones of these libraries were sequenced using pUCF and pUCR and subsequent primer walking. Finally the remaining gaps were filled by designing primers to the ends of the larger contigs, orientating these contigs by PCR using phage genome as template, and then primer walking out from the contigs using the PCR amplified products as sequencing template. The genomic sequence was assembled using the Lasergene SeqMan 7.0 program (DNAStar). Final coverage of the genome was 4fold with the majority sequenced on both of the strands or, where bidirectional sequencing was impractical, with multiple sequence runs on the same strand.

\section{Bioinformatics}

Potential ORFs were assigned using the programs FGENESB [38] and GeneMark.hmm v2.5a [39]. tRNA sequences were identified using the tRNAscan-SE program in [40]. Translations of potential ORF sequences to amino acids were made with the SeqBuilder program (DNAStar). Statistics for each of the ORFs were calculated using the program ProtParam [41].

GC skew was calculated using the online base composition tools at [42]. BLAST (blastp and tblastn) and PSIBLAST [43] were used to search for possible homologies to known proteins, or proteins predicted by translation of the unannotated DNA sequence in GenBank. Inverted repeats in the DNA sequence were identified using Einverted [44] and PALINDROME [45]; direct repeats were located using Palim [46].

\section{Authors' contributions}

Eulyn Pagaling collected samples on the field trip, did all of the culture and virus isolation work and analysed and interpreted data and revised the manuscript. Richard Haigh determined and analysed much of the genomic sequence data and revised the manuscript. W Grant, D Cowan, B Jones, Y Ma, and A Ventosa, participated in the experimental design, collected samples on the field trip analysed and interpreted data and revised the manuscript. Shaun Heaphy participated in the experimental design, collected samples on the field trip, supervised laboratory work, analysed and interpreted data and wrote the manuscript. All authors read and approved the final manuscript.

\section{Acknowledgements}

This research was supported by the European Commission research programme.

'Quality of life and management of living resources', project MultigenomeAccess Technology for Industrial Catalysts (QLRT-200I-01972).

\section{References}

I. Wheelis ML, Kandler O, Woese CR: On the nature of global classification. Proc Natl Acad Sci USA 1992, 89:2930-2934.

2. Angly FE, Felts B, Breitbart M, Salamon P, Edwards RA, Carlson C, Chan AM, Haynes M, Kelley S, Liu H, Mahaffy JM, Mueller JE, Nulton J, Olson R, Parsons R, Rayhawk S, Suttle CA, Rohwer F: The marine viromes of four oceanic regions. PLoS Biol 2006, 4:e368.

3. Breitbart M, Hewson I, Felts B, Mahaffy JM, Nulton J, Salamon P, Rohwer F: Metagenomic analyses of an uncultured viral community from human feces. J Bacteriol 2003, 185:6220-6223.

4. Breitbart M, Salamon P, Andresen B, Mahaffy JM, Segall AM, Mead D, Azam F, Rohwer F: Genomic analysis of uncultured marine viral communities. Proc Natl Acad Sci USA 2002, 99: I 4250-14255.

5. Cann AJ, Fandrich SE, Heaphy S: Analysis of the virus population present in equine faeces indicates the presence of hundreds of uncharacterized virus genomes. Virus Genes 2005, 30:151-156.

6. Edwards R, Rohwer F: Viral metagenomics. Nat Rev Microbiol 2005, 3:504-5I0.

7. Virus Taxonomy: Classification and Nomenclature of Viruses. Edited by: Fauquet CM, Mayo MA, Maniloff J, Desselberger U, Ball LA. Elsevier, Amsterdam; 2005.

8. Ackermann HW: $\mathbf{5 5 0 0}$ Phages examined in the electron microscope. Arch Virol 2007, 152:227-243.

9. Prangishvili D, Forterre P, Garrett RA: Viruses of the Archaea: a unifying view. Nat Rev Microbiol 2006, 4:837-848. 
10. Barns SM, Delwiche CF, Palmer JD, Pace NR: Perspectives on archaeal diversity, thermophily and monophyly from environmental rRNA sequences. Proc Natl Acad Sci USA 1996, 93:9188-9193.

II. Huber H, Hohn MJ, Rachel R, Fuchs T, Wimmer VC, Stetter KO: A new phylum of Archaea represented by a nanosized hyperthermophilic symbiont. Nature 2002, 417:63-7.

12. Dyall-Smith M, Tang SL, Bath C: Haloarchaeal viruses: how diverse are they? Res Microbiol 2003, I54:309-3/3.

13. Klein R, Baranyi U, Rossler N, Greineder B, Scholz H, Witte A: Natrialba magadii virus $\phi \mathrm{Ch} \mathrm{I}$ : first complete nucleotide sequence and functional organization of a virus infecting a haloalkaliphilic archaeon. Mol Microbiol 2002, 45:85I-863.

14. Tang SL, Nuttall S, Dyall-Smith M: Haloviruses HFI and HF2: evidence for a recent and large recombination event. J Bacterio 2004, 186:2810-2817.

15. Tang SL, Nuttall S, Ngui K, Fisher C, Lopez P, Dyall-Smith M: HF2: a double-stranded DNA tailed haloarchaeal virus with a mosaic genome. Mol Microbiol 2002, 44:283-296.

16. Bath C, Cukalac T, Porter K, Dyall-Smith M: His I and His2 are distantly related, spindle-shaped haloviruses belonging to the novel virus group, Salterprovirus. Virology 2006, 350:228-239.

17. Bamford DH, Ravantti J], Ronnholm G, Laurinavicius S, Kukkaro P, Dyall-Smith M, Somerharju P, Kalkkinen N, Bamford JK: Constituents of SHI, a novel lipid-containing virus infecting the halophilic euryarchaeon Haloarcula hispanica. J Virol 2005, 79:9097-9107

18. Porter K, Kukkaro P, Bamford JK, Bath C, Kivela HM, Dyall-Smith ML, Bamford DH: SHI: A novel, spherical halovirus isolated from an Australian hypersaline lake. Virology 2005, 335:22-33.

19. McGenity T], Grant WD: Genus Halorubrum. In Bergey's Manual of Systematic Bacteriology Volume I. 2nd edition. Edited by: Boone DR Castenholz RW. Springer; 2001:320-324.

20. Cui HL, Tohty D, Zhou PJ, Liu SJ: Halorubrum lipolyticum sp. nov. and Halorubrum aidingense sp. nov., isolated from two salt lakes in Xin-Jiang, China. Int J Syst Evol Microbiol 2006, 56: $1631-1634$

21. Grigoriev A: Strand-specific compositional asymmetries in double-stranded DNA viruses. Virus Res 1999, 60:1-19.

22. Bell SD, Jackson SP: Transcription and translation in Archaea: a mosaic of eukaryal and bacterial features. Trends Microbiol 1998, 6:222-228.

23. Sartorius-Neef S, Pfeifer F: In vivo studies on putative Shine-Dalgarno sequences of the halophilic archaeon Halobacterium salinarum. Mol Microbiol 2004, 51:579-588.

24. Tolstrup N, Sensen CW, Garrett RA, Clausen IG: Two different and highly organized mechanisms of translation initiation in the archaeon Sulfolobus solfataricus. Extremophiles 2000 , 4:175-179.

25. Mongodin EF, Nelson KE, Daugherty S, Deboy RT, Wister J, Khouri H, Weidman J, Walsh DA, Papke RT, Sanchez Perez G, Sharma AK, Nesbo CL, MacLeod D, Bapteste E, Doolittle WF, Charlebois RL, Legault B, Rodriguez-Valera F: The genome of Salinibacter ruber: convergence and gene exchange among hyperhalophilic bacteria and archaea. Proc Natl Acad Sci USA 2005, 102:18147-18152.

26. Bickle TA, Krüger DH: Biology of DNA restriction. Microbiol Rev 1993, 57:434-450

27. Holmes ML, Nuttall SD: Construction and use of halobacterial shuttle vectors and further studies on Haloferax DNA gyrase. J Bacteriol I991, 173:3807-3813.

28. Allers T, Mevarech M: Archaeal genetics - the third way. Nature Rev Genet 2005, 6:58-73.

29. Zillig W, Prangishvilli D, Schleper C, Elferink M, Holz I, Albers S, Janekovic D, Gotz D: Viruses, plasmids and other genetic elements of thermophilic and hyperthermophilic Archaea. FEMS Microbiol Rev 1996, 18:225-236.

30. Stolt $\mathrm{P}$, Zillig $\mathrm{W}$ : Transcription of the halophage phi $\mathbf{H}$ repressor gene is abolished by transcription from an inversely oriented lytic promoter. FEBS Lett 1994, 344: | 25- 128.

31. Purdy KJ, Cresswell-Maynard TD, Nedwell DB, McGenity TJ, Grant WD, Timmis KN, Embley TM: Isolation of haloarchaea that grow at low salinities. Environ Microbiol 2004, 6:59I-595.

32. Rees HC, Grant WD, Jones BE, Heaphy S: Diversity of Kenyan soda lake alkaliphiles assessed by molecular methods. Extremophiles 2004, 8:63-7I.
33. Weisburg WG, Barns SM, Pelletier DA, Lane DJ: I6S ribosomal DNA amplification for phylogenetic study. J Bacteriol 1991, I 73:697-703.

34. Altschul SF, Gish W, Miller W, Myers EW, Lipman DJ: Basic local alignment search tool. J Mol Biol 1990, 21 5:403-4I0.

35. Kumar S, Tamura K, Nei M: MEGA3: Integrated software for Molecular Evolutionary Genetics Analysis and sequence alignment. Brief Bioinform 2004, 5:150-163.

36. Upgrade [http://rsb.info.nih.gov/ii/upgrade/index.html]

37. de Lorenzo V, Herrero M, Jakubzik U, Timmis KN: Mini-Tn5 transposon derivatives for insertion mutagenesis, promoter probing, and chromosomal insertion of cloned DNA in Gramnegative eubacteria. J Bacteriol 1990, 172:6568-6572.

38. Softberry [http://www.softberry.com]

39. GeneMark [http://opal.biology.gatech.edu/GeneMark/index.html]

40. tRNAscan-SE Search Server [http://lowelab.ucsc.edu/tRNAs can-SE/]

4I. ProtParam tool [http://www.expasy.ch/tools/protparam.html]

42. DNA base composition analysis tool [http://molbiol-tools.ca/ lie Zheng]

43. NCBI/BLAST home [http://www.ncbi.nlm.nih.gov/BLAST/]

44. emboss einverted [http://bioweb.pasteur.fr/docs/EMBOSS/ein verted.html]

45. PALINDROME [http://bioweb.pasteur.fr/seqanal/interfaces/palin drome.html]

46. PROTEOME ALLIANCE [http://tp/2.pzr.uni-rostock.de/ moe ler/palim/index.html]

Publish with Biomed Central and every scientist can read your work free of charge

"BioMed Central will be the most significant development for disseminating the results of biomedical research in our lifetime. "

Sir Paul Nurse, Cancer Research UK

Your research papers will be:

- available free of charge to the entire biomedical community

- peer reviewed and published immediately upon acceptance

- cited in PubMed and archived on PubMed Central

- yours - you keep the copyright
BioMedcentral 